\title{
Pemanfaatan Data Pokok Pendidikan Jenjang SD Dalam Mempengaruhi Formulasi Kebijakan Pemerintah Daerah Pada Dinas Pendidikan di Kabupaten Biak Numfor
}

\author{
Samar ${ }^{1}$, Rudiyansyah ${ }^{2}$, Nur Inayati Saipul ${ }^{3}$ \\ ${ }^{1}$ Program Studi Administrasi Publik, institut IImu Sosial dan Ilmu Politik Yapis Biak \\ Email : syam.todang@gmail.com \\ ${ }^{2}$ Program Studi Administrasi Publik, institut IImu Sosial dan IImu Politik Yapis Biak \\ Email : rudyansyah488@gmail.com \\ ${ }^{3}$ Program Studi Administrasi Publik, institut Ilmu Sosial dan Ilmu Politik Yapis Biak \\ Email : nurinayatisaiful@gmail.com
}

\begin{abstract}
The purpose of this study was to find out basic information about primary school level education in influencing the formulation of local government policies at the education office in Biak Numfor district. This study uses a qualitative descriptive method that describes the influence of local government policy formulations through the education office. Utilization of the main data system or abbreviated as DAPODIK and its influence on local government policies in the education sector, the researcher takes several important things from this research such as the use of the dapodic application system in schools in inputting educational data which is still not maximal in its utilization. This can be seen through the activities of utilizing DAPODIK in elementary schools (SD) in Biak district but still manually carried out by the school principal. In addition, the existence of several inhibiting factors in the use of the DAPODIK system is inseparable from the number of school operators who do not understand the use of the DAPODIK information system such as 1 . There is no access to service operators in the DAPODIK information system organization so that if there are school operators who report problems the system is difficult to fix. Direct, 2. School operators who are complicated in managing education data and competencies possessed by school operators in using the DAPODIK management system and DAPODIK school operators are still manually done by schools, 3. The supporting factors referred to in the use of DAPODIK based on the results of this discussion are a collection computer information in inputting school education data. The SDM in operating and inputting basic school education data, with a sufficient budget in its operations and the influence of the internet for the DAPODIK upload process. Forms of government policies that can be related to the use of the DAPODIK application are policies that pay attention to government needs to the needs of educators with a student ratio that is Yes, budget allocation for improving education infrastructure is right on target and correcting other problems related to education.
\end{abstract}

Keywords : Utilization of DAPODIK, Influence, Policy Formulation.

\begin{abstract}
Abstrak. Tujuan dari penelitian ini, untuk mengetahui pemanfaatan data pokok pendidikan jenjang sekolah dasar dalam mempengaruhi formulasi kebijakan pemerintah daerah pada dinas pendidikan dikabupaten biak numfor. Penelitian ini menggunakan metode deskriptif kualitatif yang menggambarkan pengaruh formulasi kebijakan pemerintah daerah melalui dinas pendidikan. Pemanfataan sistem data pokok atau disingkat dengan DAPODIK dan pengaruhnya terhadap kebijakan pemerintah daerah pada sektor pendidikan maka peneiliti mengamb beberapa hal yang penting dari penelitian ini seperti pemanfataan sistem aplikasi dapodik pada sekolah dalam melakukan input data pendidikan masih kurang maksimal dalam pemanfataannya. Hal ini dapat dilihat melalui kegiatan pemanfaatan DAPODIK pada sekolah dasar (SD) di kabupaten biak numfor masih manual dilakukan oleh kepala sekolah. Selain itu adanya beberapa faktor penghambat dalam pemanfaatan sistem DAPODIK tersebut tidak terlepas banyaknya operator sekolah yang kurang memahami dalam penggunaan sistem informasi DAPODIK seperti, 1. tidak ada akses operator dinas dalam mengelola sistem
\end{abstract}


informasi DAPODIK sehingga kalau ada operator sekolah yang melaporkan permasalahan sistemnya susah untuk memperbaiki langsung, 2. Operator sekolah merasa rumit dalam pengaturan data pendidikan dan kurangnya kompetensi yang dimiliki oleh operator sekolah dalam menggunakan sistem pengelolaan DAPODIK dan operator DAPODIK sekolah masih manual dikerjakan oleh kepala sekolah, 3. Adapun faktor pendukung yang dimaksud dalam pemanfaatan DAPODIK berdasarkan hasil pembahasan ini adalah ketersediaan fasilitas komputer dalam penginputan data pendidikan sekolah. Ketersediaan SDM dalam mengoprasikan dan penginputan data pokok pendidikan sekolah, ketersediaan anggaran yang cukup dalam operasionalnya dan ketersediaan internet untuk proses upload DAPODIK. Bentuk kebijakan pemerintah dapat berkaitan dengan penggunaan aplikasi DAPODIK adalah kebijakan-kebijakan yang menyangkut perhatian pemerintah terhadap kebutuhan tenaga pendidik dengan rasio siswa yang ada, pengelokasian anggaran dalam meningkatkan infrastruktur pendidikan nyang tepat sasaran dan pembenahan masalah-maslah lainnya terkait dengan pendidikan.

Kata Kunci : Pemanfaatan DAPODIK, Pengaruh, Formulasi Kebijakan.

\section{PENDAHULUAN}

Direktorat Jendral Pendidikan Dasar (Ditjen Dikdas) telah memanfaatkan sistem informasi dalam pengolahan data pokok pendidikan dasar. Data-data tersebut diatur dengan sistem informasi data pokok pendidikan dasar (Dapodikdas). Dapodik adalah sistem informasi yang mengatur dan mengolah data pokok pendidikan dasar yang terpadu, diantaranya data sekolah, tenaga kependidikan, peserta didik, periodik, sanitasi, rombongan belajar (rombel), dan data sarana prasarana sekolah. Dalam rangka melaksanakan perencanaan pendidikan maupun program-program pendidikan secara tepat sasaran, dibutuhkan data yang cepat, lengkap, valid dan up to date. Dengan ketersediaan data yang cepat, lengkap, valid dan up to date, maka proses perencanaan, pelaksanaan, pelaporan dan evaluasi kinerja program-program pendidikan nasional dapat dilaksanakan dengan lebih terukur, tepat sasaran, efektif, efisien.

Data Pokok Pendidikan atau Dapodik merupakan sistem pendataan skala nasional yang terpadu, dan menjadi satu - satunya sumber data utama pendidikan nasional, yang merupakan bagian dari Program perancanaan pendidikan nasional dalam mewujudkan insan Indonesia yang Cerdas dan Kompetitif. Karena tanpa perencanaan pendidikan yang matang, maka seluruh program yang terbentuk dari perencanaan tersebut akan jauh dari tujuan yang diharapkan. Untuk melaksanakan perencanaan pendidikan, maupun untuk melaksanaan program-program pendidikan secara tepat sasaran, dibutuhkan data yang cepat, lengkap, valid, akuntabel dan terus up to date. Dengan ketersediaan data yang cepat, lengkap, valid, akuntabel dan up to date tersebut, maka proses perencanaan, pelaksanaan, pelaporan dan evaluasi kinerja program-program pendidikan nasional dapat dilaksanakan dengan lebih terukur, tepat sasaran, efektif, efisien dan berkelanjutan.

Sehubungan dengan hal tersebut, Departemen Pendidikan Nasional telah mengembangkan suatu sistem pendataan skala nasional yang terpadu dan disebut dengan Data Pokok Pendidikan (Dapodik). Dapodik ini dikelola oleh biro PKLN (Biro Perencanaan dan Kerjasama Luar Negeri) sampai tanggal 30 Maret 2010 diserahterimakan kepada PSP Balitbang. Data pokok pendidikan awalnya dapat diakses melalui situs dapodik.org yaitu data sejak tahun 2006 sampai 2011. Untuk data tahun 2012 tidak tersedia di situs dapodik.org karena situs tersebut telah ditutup sejak 1 Januari 2012. Berdasarkan surat edaran dari Kemdiknas no. 1980/P3/TP/2011 tanggal 14 September 2011 data NPSN dan NISN hanya dapat diakses melalui situs kemdiknas dan berkelanjutan. Dapodik ini diharapkan dapat mengatur data-data sekolah baik yang ada dipemerintahan kota maupun di kabupaten. Setiap pemerintahan kota atau kabupaten memiliki kantor induk Dinas Pendidikan dan Kebudayaan untuk mengatur, melayani dan memantau sekolah-sekolah yang ada disetiap kota atau kabupaten tersebut, salah satunya kantor Dinas Pendidikan dan Kebudayaan Kabupaten Biak Numfor.

Kantor Dinas Pendidikan dan Kebudayaan Kabupaten Biak Numfor memiliki beberapa kepala bidang salah satunya adalah Kepala Bidang Pendidikan dan Pengajaran (Kabid Dikjar) yang mengatur sekolah tingkat pendidikan dasar yaitu Sekolah Dasar (SD dan SDLB) dan Sekolah Menengah Pertama 
(SMP dan SMPLB). Kabid Dikjar ini telah menerapkan sistem dapodik disetiap pendidikan dasar tersebut.

Kepala Bidang Pendidikan dan Pengajaran (Kabid Dikjar) pada bagian pemantau sistem (Operator Dinas) telah mensosialisasikan tentang sistem dapodik pada setiap Jenjang Pendidikan yang ada di setiap Distrik yang dihadiri oleh operator sekolah yang ada di seluruh Kabupaten Biak Numfor. Di setiap masing-masing sekolah tersebut memiliki masing-masing operator sekolah (pengguna) untuk mengoperasikan sistem informasi Dapodik.

Namun dari hasil pengamatan awal yang penulis lakukan bahwa implementasi Dapodik di lapangan masih ditemukan kendala-kendala yang dialami pengguna (user : dalam hal ini adalah Operator Sekolah) dalam pengunaan sistem. Berdasarkan hasil pengamatan terhadap Operator Sekolah dan Operator Dinas, kendala atau hambatan yang dapat ditemukan adalah Banyak operator sekolah yang kurang memahami dalam penggunaan sistem informasi Dapodik, tidak ada akses untuk Operator Dinas dalam mengelola sistem informasi Dapodik sehingga kalau ada operator sekolah yang melaporkan permasalahan sistemnya susah untuk memperbaikinya langsung, operator sekolah merasa rumit dalam pengaturan data Pendidikan, kurangnya kompetensi yang dimiliki operator sekolah dalam menggunakan sistem pengelolaan Dapodik.

Perlunya identifikasi factor penghambat terhadap implementasi kebijakan pemerintah dalam pemanfaatan sistem Dapodik merupakan langkah yang tepat untuk memperbaiki sistem Pendidikan kedepan. Keterlibatan pemerintah daerah pada sector Pendidikan dalam mewujudkan program nasional tersebut merupakan tugas Dinas Pendidikan di daerah. Sehingga diperlukan adanya sinergitas antara pusat dan daerah dalam menangani dan menjalankan program nasional Pendidikan tersebut.

Pemanfaatan merupakan turunan kata dari kata 'Manfaat', yakni suatu penghadapan yang semata-mata menunjukan kegiatan menerima. Penghadapan tersebut pada umumnya mengarah pada perolehan atau pemakaian yang hal-hal yang berguna baik di pergunakan secara langsung maupun tidak langsung agar dapat bermanfaat. Sedangkan menurut Prof. Dr. J.S. Badudu dalam Kamus Umum Bahasa Indonesia, mengatakan bahwa : "Pemanfaatan adalah hal, cara, hasil kerja dalam memanfaatkan sesuatu yang berguna"

Dalam Permendikbud No. 79 Tahun 2015 tentang Data Pokok Pendidikan, yang selanjutnya disingkat Dapodik adalah suatu sistem pendataan yang dikelola oleh Kementerian Pendidikan dan Kebudayaan yang memuat data satuan pendidikan, peserta didik, pendidik dan tenaga kependidikan, dan substansi pendidikan yang datanya bersumber dari satuan pendidikan yang terus menerus diperbaharui secara online. Data pokok pendidikan atau DAPODIK adalah salah satu program pemerintah yang bertujuan untuk mengumpulkan data. Program dari kementerian pendidikan dan kebudayaan dengan sasaran Sekolah atau satuan pendidikan.

Untuk mendukung setiap aktivitas yang ada diperlukan suatu administrasi organisasi yang baik pula. Berfungsi suatu lembaga atau organisasi sangat ditentukan bagaimana tingkat pemanfaatan administrasi dalam organisasi. Hal ini mengingat sumber daya dalam suatu organisasi baik itu sumberdaya manusia, sumber daya sarana prasarana perlu diberdayakan seoptimal mungkin. Tindakan administrasi Dapodikdas dalam suatu organisasi sangat tergantung pada kemampuan pemimpin dalam menggunakan kepemimpinannya untuk memanfaatkan fasilitas yang ada. Penataan administrasi khususnya pada administrasi sumber daya manusia sangat menentukan produktifitas kerja. Semakin besarnya organisasi, maka semakin tinggi tuntutan penganalisaan terhadap perekrutan sumber daya manusia.

Berdasarkan penjelasan diatas, terkait pendukung pelaksanaan Dapodik maka secara umum dapat dijelaskan factor penghambat dalam pengelolaan sistem Dapodik bilamana unsur salahsatu unsur pendukung tidak berjalan dengan baik maka keberhasilan pelaksanaan Dapodik tidak berjalan sesuai yang diharapkan.

Kebijakan merupakan istilah yang sering kali kita dengar dalam konteks pemerintahan atau berpolitikan. Istilah kebijakan memiliki cakupan yang sangat luas. Kata "policy" yang berarti 
mengurus masalah atau kepentingan umum, atau berarti juga administrasi pemerintah (Hasbullah:2015).

Istilah kebijakan (Policy) sering kali dicampuradukkan dengan kebijaksanan (wisdom) (Tilaar dan Riant Nugroho:2009). Kedua istilah ini memang hampir sama dari segi pengucapan. Namun sebenarnya kedua istilah ini mempunyai makna yang sangat jauh berbeda. Kebijakan didasari oleh pertimbangan akal dalam proses pembuatannya. Akal manusia merupakan unsur yang dominan di dalam mengambil keputusan dari berbagai opsi dalam pengambilan keputusan kebijakan. Sedangkan kebijaksanaan lebih terpengaruh faktor emosional dalam prosesnya. Suatu kebijaksanaan bukan berarti tidak mengandung unsur-unsur rasional di dalamnya. Barangkali faktor-faktor tersebut belum tercapai pada saat itu atau merupakan intuisi.

Dalam buku Analisis kebijakan Pendidikan, Nanang Fatah (2014:135) mengutip pendapat Hogwood dan Gun yang membedakan kebijakan sebagai label untuk bidang kegiatan. Kebijakan sebagai suatu ekspresi umum dari tujuan umum atau keadaan yang diinginkan. Kebijakan sebagai proposal khusus, kebijakan sebagai keputusan pemerintah, kebijakan sebagai otorisasi formal, dan kebijakan sebagai program.

Pendidikan merupakan segala pengaruh yang diupayakan sekolah terhadap anak dan remaja (usia sekolah) yang diserahkan kepada pihak sekolah agar mempunyai kemampuan kognitif dan kesiapan mental yang sempurna dan kesadaran maju yang berguna bagi mereka untuk terjun ke masyarakat, menjalin hubungan sosial, dan memikul tanggung jawab mereka sebagai individu maupun sebagai makhluk social (Nurani Soyomukti. 2010:41).

Implikasi-implikasi terhadap substansi manajemen pendidikan, perlu ditelusuri dari komponenkomponen yang melekat pada sistem pendidikan nasional, yang saat ini memikul beban berat dalam menanggulangi krisis multidimensional. Jika berangkat dari filosofi demokratisasi, pelayanan, dan meningkatkan peran serta masyarakat dalam penyelenggaraan pendidikan yang diwujudkan dalam misi dan tugas lembaga pendidikan, diperlukan suatu kebijakan yang dituangkan dalam bentuk peraturan perundang-undangan. Kebijakan tersebut merupakan standar, spesifikasi dan model normatif ini, dipakai untuk menseleksi bahan masukan untuk diproses sehingga menghasilkan keluaran sebagaimana keinginan, kebutuhan dan harapan masyarakat dan bangsa (Yoyon Bahtiar Irianto, 2012:52 ). Kebijakan pendidikan merupakan suatu yang sifatnya esensif dan komprehensif. Kebijakan yang dibuat ditujukan untuk mengatasi suatu permasalahan yang sifatnya pelik. Kebijakan yang baik adalah kebijakan yang dibuat berdasarkan aspirasi dan berpihak kepada masyarakat dan realitas yang ada, menyahuti berbagai kepentingan dan meminimalkan adanya kerugian pihak-pihak tertentu.

Demikian pula halnya dengan kebijakan pendidikan, hendaknya harus mempertimbangkan banyak hal, karena menyangkut kepentingan publik yang dampaknya sangat besar (Hasbullah, 2014:63). Kebijakan pendidikan yang dibuat haruslah bersifat bijaksana, dalam arti tidak menimbulkan problematika pendidikan baru yang lebih besar dan rumit jika dibandingkan dengan problema yang hendak dipecahkan. Kebijakan pendidikan yang dibuat haruslah mendorong produktivitas, kualitas, dan perikehidupan bersama dalam bidang pendidikan secara efektif dan efisien. Syaiful Syagala (2008:99) mengemukakan dalam bukunya yang berjudul "Administrasi Pen didikan Kontemporer" bahwa secara umum terdapat pendekatan yang digunakan dalam pembuatan kebijakan adalah sebagai berikut:

\section{Pendekatan Empirik (Empirical Approach)}

Pendekatan empiris ditekankan terutama pada penjelasan berbagai sebab dan akibat dari suatu kebijakan tertentu dalam bidang pendidikan yang bersifat faktual dan macam informasi yang dihasilkan bersifat deskriptif dan prediktif. Analisa kebijakan secara empirik diharapkan akan menghasilkan dan memindahkan informasi penting mengenai nilai-nilai, faktafakta, dan tindakan Pendidikan.

2. Pendekatan Evaluatif (Evaluatif Approach)

Evaluasi menurut Imron adalah "salah satu aktivitas yang bermaksud mengetahui seberapa jauh suatu kegiatan itu dapat dilaksanakan ataukah tidak, berhasil sesuai yang 
diharapkan atau tidak". Penekanan pendekatan evaluatif ini terutama pada penentuan bobot atau manfaatnya (nilai) beberapa kebijakan menghasilkan informasi yang bersifat evaluatif. Evaluasi terhadap kebijakan membantu menjawab pertanyaan-pertanyaan evaluatif yaitu bagaimana nilai suatu kebijakan dan menurut nilai yang mana kebijakan itu ditentukan.

3. Adopsi/ Legitimasi Kebijakan

Legitimasi berasal dari kata "legitimacy" yang berarti memberi kuasa atau kewenangan (otorisasi) pada dasar bekerjanya sistem politik, termasuk proses penyusunan perencanaan, usul untuk memecahkan problema-problema yang tumbuh di masyarakat. Kata legitimasi juga berasal dari kata "legitimation" yang artinya suatu proses khusus dimana program-program pemerintah diabsahkan.

4. Implementasi Kebijakan

Menurut Richard Gorton dan Scheneider "Implementing inolves administrators in the process of making sure that the plant is carried out as intended" (1991:65). Artinya implementasi melibatkan seorang administrator pada proses memastikan rencana berjalan sesuai yang dikehendaki. Pada dasarnya proses implementasi kebijakan merupakan proses yang sangat menentukan. Tolok ukur keberhasilan kebijakan pendidikan dapat dilihat pada tahap implementasi. Sebaik apapun kebijakan pendidikan yang sudah dibuat jika tidak diimplementasikan maka tidak akan dapat dirasakan manfaatnya.

c. Kendala dalam Implementasi Kebijakan Pendidikan

Keberhasilan dalam implementasi kebijakan merupakan sesuatu hal yang sangat diharapkan dalam tatanan kebijakan. Karena implementasi kebijakan merupakan proses yang sifatnya sangat penting. Dapat diibaratkan implementasi kebijakan adalah penentu suatu kebijakan dapat dikatakan berhasil atau gagal. Namun proses implementasi kebijakan tidak selamanya berjalan tanpa hambatan. Terdapat beberapa kendala dalam proses implementasi kebijakan. Kendala-kendala dalam implementasi kebijakan yang oleh Dunsire yang dikutip hasbullah, dinamakan sebagai "implementation gap" yaitu suatu keadaan dalam proses kebijakan selalu terbuka untuk kemungkinan akan terjadinya perbedaan antara apa yang diharapkan oleh pembuat kebijakan dengan apa yang senyatanya dicapai (sebagai hasil atau prestasi dari pelaksanaan kebijakan).

d. Peran kebijakan Pemerintah Daerah dalam Meningkatkan Kualitas Pendidikan

Kebijakan daerah di era otonomi daerah sangat menentukan kualitas pendidikan, menurut kamus hukum dan Glosarium Otonomi Daerah, kebijakan adalah penyataan prinsip sebagai landasan pengaturan dalam pencapaian suatu sasaran. Kebijakan daerah adalah aturan, arahan, acuan, ketentuan dan pedoman dalam penyelenggaraan pemerintah daerah yang dituangkan dalam peraturan daerah, keputusan kepala daerah dan keputusan Dewan Perwakilan Rakyat Daerah dan keputusan pimpiman Dewan Perwakilan Rakyat Daerah. Kebijakan pemerintah daerah merupakan landasan pengaturan dalam pencapaian suatu sasaran. Kebijakan yang responsif merupakan produk hukum demokratis yang menganut asas keterbukaan antara rakyat dan pemerintah. Penetapan kebijakan pendidikan pemerintah daerah harus sesuai dengan kebijakan nasioanl dan provinsi.

Pemerintah harus secara bertahap meninggalkan pola top down dan menerapkan pola bottom up dalam proses kebijakan pendidikan. Berbagai keputusan Pendidikan hendaknya dimulai dan dikembangkan dengan mendorong keterlibatan kontruktif (constructive involvement) semua kelompok kepentingan (interest groups). Mereka perlu diberi ruang untuk memberikan kontribusinya dan mengekspresikan aspirasi pendidikan serta mempresentasikan dalam berbagai kebijakan pendidikan. Kebijakan-kebijakan pendidikan hendaknya tidak di buat atas dasar pilihan, preferensi, kemauan dan kepentingan para pejabat pemegang otoritas kependidikan (authority based), tetapi berdasarkan kondisi dan kebutuhan riil di daerah (research based). Kewenangan pemerintah daerah diatur dalam pasal 10 UU No.20 Tahun 2003 dinyatakan bahwa pemerintah dan pemerintah daerah berhak mengarahkan, membimbing, membantu dan mengawasi penyelenggaraan pendidikan sesuai dengan peraturan perundang-undangan yang berlaku. 
Sedangkan pada pasal 11 ayat 1 dan 2 dinyatakan bahwa pemerintah dan pemerintah daerah wajib memberikan layanan dan kemudahan, serta menjamin terselenggaranya pendidikan yang bermutu bagi setiap warga negara tanpa diskriminasi. Kemudian pemerintah dan pemerintah daerah wajib menjamin tersedianya dana guna terselenggaranya pendidikan bagi setiap warga negara yang berusia tujuh sampai dengan lima belas tahun.

\section{HASIL PENELITIAN DAN PEMBAHASAN}

\section{A. Hasil Penelitian}

Pada bab ini peneliti akan menguraikan analisis dan hasil penelitian yang telah penulis rumuskan yaitu Pemanfaatan Sistem Data Pokok Pendidikan (DAPODIK) dalam Mempengaruhi Kebijakan Pemerintah Daerah Pada Dinas Pendidikan Kabupaten Biak Numfor, yang dilakukan dari bulan mei sampai dengan bulan juli 2019. Peneliti menggunakan metode kualitatif untuk melihat kondisi alami dari satu fenomena.Pendekatan ini bertujuan memperoleh pemahaman dan menggambarkan realitas yang kompleks (Nasution, 2003:3). Penelitian kualitatif merupakan prosedur penelitian yang menghasilkan data-data deskriptif berupa kata-kata tertulis atau lisan yang didasari oleh orang atau perilaku yang diamati. Pendekatannya diarahkan pada latar dan individu secara holistik (utuh). Jadi, tidak dilakukan proses isolasi pada objek penelitian kedalam variabel atau hipotesis. Tetapi memandangnya sebagai bagian dari suatu keutuhan.

Untuk tahap analisis, yang dilakukan oleh peneliti adalah wawancara, pengumpulan data, dan analisis data yang dilakukan sendiri oleh peneliti. Untuk dapat mengetahui sejauh mana informasi yang diberikan oleh informan penelitian, peneliti menggunakan beberapa tahap Pertama wawancara dilaksanakan berdasarkan dari indikator - indikator Pemanfaatan Sistem Data Pokok Pendidikan dalam Mempengaruhi Kebijakan Pendidikan yang akan ditanyakan pada informan. Kedua, memindahkan data penelitian yang berbentuk daftar dari hasil wawancara informan. Ketiga, menganalisis hasil data wawancara yang telah dilakukan.

\section{Pemanfaatan Sistem Data Pokok Pendidikan (DAPODIK) Pada Jenjang Sekolah Dasar (SD) di Kabupaten Biak Numfor}

Sistem Informasi Data Pokok Pendidikan (Dapodik) adalah sistem informasi yang menangani data sekolah, tenaga kependidikan, peserta didik, periodik, sanitasi, rombongan belajar dan data sarana-prasarana sekolah. Sistem ini dibangun dalam rangka untuk mendapatkan data yang dibutuhkan dengan cepat, lengkap, valid dan up to date. Sehingga dalam pemanfaatan sistem Dapodik tersebut menjadi tujuan penelitian ini.

Berdasarkan hasil wawancara terhadap Kepala Bagian Pendidikan (Kabid Program) pada bagian pemantau sistem (Operator Dinas) telah mensosialisasikan tentang sistem Dapodik pada setiap UPTD yang ada di setiap kecamatan yang dihadiri oleh operator sekolah yang ada di seluruh kabupaten biak numfor. Di setiap masing-masing sekolah tersebut memiliki masing-masing operator sekolah (pengguna) untuk mengoperasikan sistem informasi Dapodik.

Berikut hasil wawancara yang dilakukan kepada Bapak Kepala Bidang Program Rudolf A. Yap, $\mathrm{SE}, \mathrm{MM}$ :

"Dalam penggunaan sistem informasi Dapodik kita sudah sosialisasikan kepada setiap sekolah yang ada di biak numfor agar pemanfaatan sistem informasi Dapodik benarbenar dilakukan dengan baik. Sehingga diharapkan data-data Pendidikan yang ada disetiap sekolah di input dalam pelaporan Data Pokok Pendidikan" (Wawancara dilakukan pada hari senin tanggal 10 Juli 2020).

Pemanfaatan sistem informasi Data Pokok Pendidikan sekolah merupakan bentuk kemudahan dalam memberikan akses pelaporan data Pendidikan setiap sekolah. Namun hasil wawancara yang peneliti lakukan dengan Operator Dinas Pendidikan, masih ada 
kendala-kendala yang dialami pengguna dalam penggunaan sistem. Wawancara kepada Operator Dinas Pendidikan (Andhika Prasetyo) :

"Dalam penggunaan sistem informasi Dapodik, masih banyak operator sekolah yang kurang memahami penggunaan sistem Dapodik. Sehingga dalam pelaporannya masih sering mengosongkan berbagai item penting" (Wawancara dilakukan pada hari senin tanggal 10 Juli 2020).

Berdasarkan hasil wawancara diatas terlihat bentuk sosialisasi pemanfaatan sistem informasi Dapodik oleh Dinas Pendidikan kepada operator sekolah belum sepenuhnya memberikan kemudahan terhadap sekolah dalam pemanfaatan sistem Dapodik. Hal tersebut dikarenakan kurangnya pemahaman operator sekolah dalam penggunaan sistem Dapodik.

\section{a. Pemanfaatan Sistem Dapodik}

Manfaat sistem informasi Data Pokok Pendidikan sekolah adalah mempermudah dalam mengakses data Pendidikan yang di input setiap sekolah. Namun seperti yang diketahui dari wawancara sebelumnya bahwa kurangnya pemahaman operator dalam pemanfaatan sistem Dapodik menjadi penghambat dalam mengakses data Pendidikan sekolah. Sehingga peneliti tertarik untuk mengembangkan pertanyaan kurang maksimalnya pemanfaatan sistem Dapodik oleh pengguna operator sekolah.

Berikut wawancara dilakukan kepada operator sekolah dasar (SD) YPK Ruth Yenures, Ibu Marry Artha Birahy :

"Rumitnya pengaturan data dalam sistem Dapodik membuat kami kesulitan dalam menginput data sekolah sehingga data yang di input terkadang kami laporkan kepada operator dinas terkait permasalahan sistem untuk perbaikan". (Wawancara dilakukan pada hari senin tanggal 11 Juli 2020)

Permasalahan yang sama juga disampaikan oleh Kepala Sekolah SD YPK Ruth Yenures, Bapak Derek Rumaropen, S.Pd :

"Kurangnya pemahaman kami dalam pemanfaatan Sistem Informasi Dapodik adalah merupakan kurangnya Sumberdaya manusia yang berkompeten dalam mengoperasikan sistem Dapodik tersebut". (Wawancara dilakukan pada hari senin tanggal 11 Juli 2020)

Kompetensi sumber daya manusia merupakan faktor utama dalam pemanfaatan sistem Data Pokok Pendidikan. Mengingat sistem Dapodik dibutuhkan operator yang berkompeten didalam penggunaan aplikasi tersebut sehingga pemanfaatan Dapodik dapat terlaksana dengan baik. Kondisi demikian telah disampaikan oleh Kepala Sekolah Dasar (SD) Inpres Fandoi, Ibu Pelegia Tetty Melviana dalam hasil wawancara:

" Tidak adanya Sumber Daya Manusia (Operator) yang berkompeten dalam menggunakan Sistem Aplikasi Dapodik yang membuat sekolah kesulitan dalam penginputan data kedalam pelaporan Dapodik". (Wawancara dilakukan pada hari senin tanggal 12 Juli 2020).

Pemanfaatan sistem Data Pokok Pendidikan oleh Operator Dapodik jenjang Sekolah Dasar (SD) pada kabupaten Biak Numfor masih kurang efektif karena kurangnya kompetensi SDM yang dimiliki sekolah dalam memanfaatkan Aplikasi Dapodik dengan baik. 


\section{b. Kemampuan Operator dalam Memanfaatkan Sistem Dapodik}

Berdasarkan hasil wawancara sebelumnya bahwa kemampuan operator Dapodik Sekolah merupakan penentu dalam memanfaatkan sistem aplikasi Dapodik dengan baik.

Berikut hasil wawancara dilakukan kepada Operator Dapodik Pada Dinas Pendidikan Kabupaten Biak Numfor :

"Kurangnya SDM (Operator) yang dimiliki oleh Sekolah Dasar (SD) di Kabupaten Biak Numfor menjadi kendala dalam pemanfaatan sistem Dapodik. Hal ini membuat kami kesulitan dalam memberikan pelayanan karena masalah SDM yang ada pada setiap sekolah". (Wawancara dilakukan pada hari senin tanggal 15 Agustus 2020)

Permasalahan yang sama diutarakan Bapak Kabid Program pada Dinas Pendidikan Kabupaten Biak Numfor bahwa kurangnya SDM yang menjadi penghambat dalam pengelolaan data pada Sistem Aplikasi Dapodik. Berikut hasil wawancara yang dilakukan kepada Bapak Kabid Program Rudolf A. Yap, SE, MM :

"Memang SDM yang dimiliki setiap sekolah di Kabupaten Biak Numfor menjadi kendala kami untuk menjalankan kebijakan ini dalam pemanfaatan sistem Dapodik. Permasalahan ini sudah kami diskusikan kepada stakeholder sehingga kedepan dicarikan solusi". (Wawancara dilakukan pada hari senin tanggal 15 Agustus 2020)

Dalam pemanfaatan sistem aplikasi Dapodik pada dasarnya dibutuhkan SDM yang mumpuni dalam pengoperasian computer utamanya dalam penggunaan Aplikasi Sistem Data Pokok Pendidikan sekolah. Kurangnya SDM pada setiap sekolah dalam pengelolaan data Pendidikan berbasis aplikasi menjadikan pemerintah Daerah untuk dilakukan perencanaan dalam membuat formulasi kebijakan pada sektor Pendidikan. Seperti diketahui bahwa majunya sebuah daerah tergantung pada SDM yang dimiliki dalam penyelenggaraan pelayanan public.

Hari Pendidikan Nasional Pemerintah Daerah melalui Bupati Biak Numfor mengatakan, untuk penguatan di dunia pendidikan terutama untuk ketersedian SDM pada seluruh satuan Pendidikan di Kabupaten Biak Numfor harus berani mengalokasikan dana yang cukup besar untuk hal tersebut http://analisapublik.com/2019/05/02/hardiknas-bupati-biak-numfor-fokus-penuhi-ketersedian-guru

\section{Pengaruh Pemanfaatan Sistem Dapodik Terhadap Kebijakan Pendidikan}

Salah satu tujuan dari pemanfaatan sistem Dapodik untuk membantu pengadministrasian data pada satuan pendidikan maka pemerintah mengeluarkan sebuah aplikasi yang diberi nama Data Pokok Pendidikan yang di singkat Dapodik. Aplikasi ini dibangun untuk mendapatkan data yang berkualitas dan data ini nantinya akan menentukan kebijakan pemerintah pusat dalam menentukan seperti halnya rasio tenaga kependidikan, syarat untuk menentukan tunjangan profesi guru (TPG), Biaya Operasional Sekolah (BOS) dan masih banyak lagi kebijakan-kebijakan pusat yang nantinya akan melakukan pengambilan datanya dari aplikasi Dapodik, maka dari itu satuan pendidik harus melakukan Input Data maupun Update data sesuai dengan bukti fisik yang ada kedalam Aplikasi Dapodik untuk mendapatkan data yang akurat cepat, lengkap, valid dan up to date, maka Operator Sekolah berperan penting dalam melakukan pendataan dan sekaligus pengguna dari aplikasi Dapodik tersebut.

Kondisi demikian mengarahkan pemerintah untuk mendorong pembangunan melalui kebijakan pada sektor Pendidikan. Pemanfaatan Dapodik menjadi salah satu cara dalam melakukan pengawasan terhadap permasalahan yang dihadapi sekolah yang selanjutnya menjadi acuan pemerintah untuk melakukan langkah-langkah perubahan untuk peningkatan kualitas Pendidikan di Indonesia.

Bentuk kebijakan yang dimaksud dalam keterkaitannya penggunaan Aplikasi Dapodik adalah kebijakan-kebijakan yang menyangkut perhatian pemerintah terhadap kebutuhan tenaga pendidik dengan rasio siswa yang ada, pengalokasian anggaran dalam meningkatkan infrastruktur Pendidikan 
yang tepat sasaran dan pembenahan masalah-masalah lainnya terkait Pendidikan. Permasalahan yang tentunya dapat dilihat melalui pelaporan data sekolah yang di input dalam aplikasi Dapodik tersebut.

\section{a. Kebijakan pemerintah daerah terhadap pemanfaatan sistem Dapodik di Sekolah}

Secara garis besar di Indonesia,terdapat dua jenis kebijakan yaitu yang bersifat sentralistik dan desentralistik. Kebijakan desentralistik adalah langkah yang diambil untuk mensinkronkan dengan kondisi di setiap satuan pendidikan yang tidak sama. Salah satunya adalah melalui MBS (Manajemen Berbasis Sekolah).

Kebijakan pendidikan dimanifestasikan dalam pemberian otonomi pada sekolah, akan meningkatkan kapasitas dan memperbaiki manajemen sekolah. Dengan kewenangan penuh yang dimiliki sekolah, maka sekolah lebih leluasa mengelola dan mendayagunakan potensi sumber daya yang dimiliki, misalnya, keuangan, tenaga pengajar (guru), kurikulum, sarana prasarana, dan lainlain. Dengan demikian, desentralisasi diharapkan dapat meningkatkan mutu pendidikan dan memperbaiki mutu belajar-mengajar, karena proses pengambilan keputusan dapat dilakukan langsung di sekolah oleh guru, kepala sekolah, dan tenaga administratif (staf manajemen). Bahkan yang lebih penting lagi, desentralisasi dapat mendorong dan membangkitkan gairah serta semangat mereka untuk bekerja lebih giat dan lebih baik.

Dalam rangka meningkatkan mutu Pendidikan, pemerintah telah mengalokasikan anggaran yang cukup besar untuk perbaikan pada sektor Pendidikan. Seperti halnya Pemerintah Daerah Kabupaten Biak Numfor dalam mewujudkan prioritas pembangunan nasional untuk mencerdaskan anak bangsa maka pemerintah daerah telah mendapatkan tambahan dana alokasi umum sebesar 200 miliar dengan prioritas utama pada sektor Pendidikan. http://analisapublik.com/2019/05/02/hardiknas-bupati-biak-numfor

Prioritas pembangunan pada sektor Pendidikan pemerintah daerah melalui Dinas Pendidikan dan Kebudayaan Kabupaten Biak Numfor membenarkan hal tersebut melalui hasil wawancara peneliti kepada Bapak Kabid Pendidikan dan Pengajaran Japosman Situmorang, S.Sos, MM.Pd :

"Saat ini pemerintah daerah telah memfokuskan pembangunan pada sektor Pendidikan. Hal tersebut telah di intruksikan oleh Bapak Bupati Herry Ario Naap pada peringatan Hari Pendidikan Nasional kemarin sehingga kekurangan guru dan pembenahan pada sektor lainnya menyangkut fasilitas Pendidikan serta tunjangan untuk tenaga teknis"(Wawancara dilakukan pada hari senin tanggal 15 Agustus 2020)

Penguatan kebijakan pada sektor Pendidikan melalui prioritas pangalokasian anggaran seakan menjadi angin segar seluruh jenjang sekolah di kabupaten biak numfor. Hal ini terlihat berdasarkan keterangan dari hasil wawancara peneliti kepada salah satu kepala sekolah SD Kemala Bhayangkari 01 Wawancara dilakukan kepada Kepala Sekolah SD Kemala Bhayangkari 01 Bapak Ali Mu'in :

"Secara umum kami harapkan apa yang disampaikan Bapak Bupati dalam peringatan Hardiknas kemarin dapat direalisasikan dengan baik mengingat saat ini kami kesulitan dalam pemberian insentif terhadap guru dan utamanya tenaga Operator teknis yang pada dasarnya tidak punya alokasi anggaran" (Wawancara dilakukan pada hari senin tanggal 13 September 2020) Selanjutnya pendapat yang sama juga diungkapkan oleh Kepala Sekolah SD YPPK Santo Yoseph 1 Ibu Christiana Sulastri :

"Kebijakan Pemerintah dalam penguatan Pendidikan dengan alokasi anggaran yang ada. Kami pihak sekolah mengharapkan bantuan pemerintah untuk betul-betul memprioritaskan anggaran Pendidikan karena selain kekurangan tenaga pendidik juga tidak adanya anggaran untuk sekolah dalam menggaji (Insentif) Operator Dapodik". (Wawancara dilakukan pada hari senin tanggal 14 september 2020) Hal yang berbeda diungkapkan oleh salah satu Kepala Sekolah 
SD Yapis 1, bahwa permasalahan yang dihadapinya lebih kepada tugas tambahan yang didapatkan para Kepala Sekolah dalam pengoperasian Aplikasi sistem Dapodik. Wawancara dilakukan kepada Bapak Ngarisan selaku Kepala Sekolah SD Yapis 1 :

"Pemanfaatan sistem Dapodik ini mempunyai sisi positif dan negatifnya karena selain Pemerintah dapat mengakses Data Sekolah secara langsung melalui Aplikasi Dapodik tersebut juga memberikan tambahan beban kerja buat kami Kepala Sekolah untuk pengoperasiannya dalam input data Pendidikan sekolah yang pada dasarnya kami masih kurang paham. Sementara kami menggunakan jasa guru yang punya kompetensi dalam penggunaannya juga mengeluh karena menghambat proses pembelajaran terhadap siswa".

Pada dasarnya pemanfaatan sistem Data Pokok Pendidik (Dapodik) oleh seluruh sekolah memang menjadi beban bagi Kepala Sekolah. Hal tersebut dikarenakan Kepala Sekolah harus paham dalam pengoperasian Aplikasi sistem Dapodik agar kebenaran data Pendidikan yang di input benar-benar valid. Disisi lain, kemampuan dan SDM yang ada masih banyak Kepala Sekolah belum memahami pemanfaatan Aplikasi Dapodik secara baik sehingga memaksa kebanyakan Kepala Sekolah untuk menggunakan jasa guru yang mampu mengoperasikan penggunaan Aplikasi Dapodik tersebut. Namun, diakui bahwa para guru juga mengalami beban dengan tugas tambahan yang diberikan karena menghambat proses pembelajaran terhadap siswa.

\section{b. Dampak Pemanfaatan Sistem Dapodik}

Dampak pemanfaatan sistem Dapodik disini penulis membagi dalam dua dampak yang dihasilkan yaitu dampak positif dan negatif. Dampak positif lebih kepada kemudahan dalam mengakses data Pendidikan sekolah seperti yang telah dijelaskan sebelumnya bahwa Aplikasi ini dibangun untuk mendapatkan data yang berkualitas dan data ini nantinya akan menentukan kebijakan pemerintah pusat dalam menentukan arah kebijakan pada sektor Pendidikan. Sebagaimana diketahui bahwa manfaat penggunaan sistem Aplikasi Dapodik adalah untuk mempermudah penginputan data Pendidikan seluruh sekolah agar dapat diakses. Sehingga stakeholder yang punya kepentingan dalam pemanfaatan data pokok Pendidikan tersebut dapat mengaksesnya.

Sejalan dengan keterangan diatas Bapak Kabid Program memberikan keterangannya terkait dampak positif yang dihasilkan dalam pemanfaatan sistem aplikasi Dapodik dengan baik. Wawancara dilakukan kepada Bapak Rudolf Alfred Yap, SE, MM selaku Kabid Program,

"Sebenarnya sistem Aplikasi Dapodik mempermudah kami ditingkat daerah untuk mengakses Data Pokok Pendidikan setiap sekolah manakala data yang dilaporkan dalam aplikasi ini dapat dilaksanakan setiap sekolah"(Wawancara dilakukan pada hari senin tanggal 10 Oktober 2020).

Pada dasarnya sistem Aplikasi Dapodik memberikan kemudahan pemerintah baik ditingkat daerah dan pusat bidang Pendidikan untuk dilakukan validasi data dan pembenahan dalam kebijakan selanjutnya untuk memperbaiki sistem Pendidikan yang ada. Selanjutnya, bahasan dampak negatif lebih kepada kurangnya kesiapan sekolah dalam menghadapi penggunaan sistem Dapodik dikarenakan pemerintah belum memahami kondisi sekolah dalam sisi SDM yang dimiliki yaitu Operator pengguna Dapodik. Operator Dapodik saat ini masih manual dikerjakan oleh Kepala Sekolah sehingga menghambat dari sisi waktu dan beban kerja tambahan diluar tujuan peningkatan mutu pembelajaran sekolah. Seperti diketahui bahwa pemerintah belum mengalokasikan anggaran terhadap perekrutan SDM yang khusus dalam pengoperasian pelaporan data Pendidikan disetiap sekolah melalui sistem Aplikasi Dapodik.

Sebagaimana diketahui bahwa dalam penggunaan aplikasi Dapodik masih manual dilakukan oleh kepala sekolah yang pada dasarnya belum mampu memanfaatkan aplikasi Dapodik 
secara baik yang terkadang harus bolak balik dari sekolah ke operator dinas Pendidikan untuk dilakukan perbaikan sistem. Disatu sisi operator dinas Pendidikan mengalami hambatan dalam membagi waktu dengan kepala sekolah dikarenakan kurangnya personel operator Dapodik pada kantor Dinas Pendidikan dengan jumlah seluruh jenjang sekolah yang cukup banyak. Maka kondisi seperti ini seharusnya pemerintah lebih pro aktif dalam melihat kondisi SDM yang ada di sekolah-sekolah sehingga ada upaya dalam membenahi kekurangan SDM yang dimiliki sekolah dan tidak menghambat para kepala sekolah dan guru untuk lebih focus pada peningkatan mutu Pendidikan. Memang tidak dipungkiri bahwa Dapodik merupakan salah satu aspek indikator dalam melihat mutu Pendidikan namun yang perlu dipikirkan adalah manajemen SDM itu sendiri. Manajemen SDM pada sekolah bukan berarti hanya berbicara pada tenaga pendidik atau kekurangan Guru akan tetapi pemenuhan tenaga tekhnis dalam membantu sekolah untuk pelaporan Data Pendidikan melalui aplikasi sistem Dapodik sebagai bagian dari program pemerintah pusat.

\section{Faktor Penghambat dan Pendukung dalam Pemanfaatan Sistem Dapodik di Kabupaten Biak Numfor}

\section{a. Faktor Penghambat}

Adapun yang menjadi faktor penghambat dalam pemanfaatan sistem Dapodik secara umum telah dijelaskan pada pembahasan sebelumnya. Berdasarkan pada pembahasan diatas penulis kemudian membagi faktor penghambat tersebut sebagaimana atas pernyataanpernyataan responden. Berikut:

1) Banyak operator sekolah yang kurang memahami dalam penggunaan sistem informasi Dapodik;

2) Tidak ada akses untuk Operator Dinas dalam mengelola sistem informasi Dapodik sehingga kalau ada operator sekolah yang melaporkan permasalahan sistemnya susah untuk memperbaikinya langsung;

3) Operator sekolah merasa rumit dalam pengaturan data Pendidikan.

4) Kurangnya kompetensi yang dimiliki operator sekolah dalam menggunakan sistem pengelolaan Dapodik

5) Operator Dapodik sekolah masih manual dikerjakan oleh Kepala Sekolah

\section{b. Faktor Pendukung}

Adapun faktor pendukung yang dimaksud dalam pemanfaatan Dapodik berdasarkan hasil pemebahasan sebelumnya adalah sebagai berikut:

1. Ketersediaan fasilitas komputer dalam penginputan data Pendidikan sekolah

2. Ketersediaan SDM dalam mengoperasikan dan penginputan Data Pokok Pendidikan Sekolah

3. Ketersediaan anggaran yang cukup dalam operasionalnya

4. Ketersediaan jaringan internet untuk proses upload Dapodik.

Ketersediaan faktor pendukung diatas dimaksudkan agar dalam proses pemanfaatan sistem Dapodik dapat terlaksana dengan baik agar kedepan mutu Pendidikan lebih fleksibel tanpa sistem yang manual.

Berdasarkan hasil penelitian pada wawancara yang telah dilakukan agar lebih focus penulis kemudian membahas hasil penelitian ini bahwa pemanfaatan sistem data pokok Pendidikan pada jenjang Sekolah Dasar atau disingkat SD di Kabupaten Biak Numfor dapat diuraikan sebagai berikut.

Sistem Informasi Data Pokok Pendidikan (Dapodik) adalah sistem informasi yang menangani data sekolah, tenaga kependidikan, peserta didik, periodik, sanitasi, rombongan belajar dan data sarana-prasarana sekolah. Sistem ini dibangun dalam rangka untuk 
mendapatkan data yang dibutuhkan dengan cepat, lengkap, valid dan up to date. Sementara dalam bentuk sosialisasi pemanfaatan sistem informasi Dapodik oleh Dinas Pendidikan kepada operator sekolah belum sepenuhnya memberikan kemudahan terhadap sekolah dalam pemanfaatan sistem Dapodik. Hal tersebut dikarenakan kurangnya pemahaman operator sekolah dalam penggunaan sistem Dapodik.

Sementara perlu diketahui bahwa Manfaat sistem informasi Data Pokok Pendidikan sekolah adalah mempermudah dalam mengakses data Pendidikan yang di input setiap sekolah. Namun seperti yang diketahui dari hasil penelitian bahwa kurangnya pemahaman operator dalam pemanfaatan sistem Dapodik menjadi penghambat dalam mengakses data Pendidikan sekolah.

Salah satu tujuan dari pemanfaatan sistem Dapodik untuk membantu pengadministrasian data pada satuan pendidikan maka pemerintah mengeluarkan sebuah aplikasi yang diberi nama Data Pokok Pendidikan yang di singkat Dapodik. Aplikasi ini dibangun untuk mendapatkan data yang berkualitas dan data ini nantinya akan menentukan kebijakan pemerintah pusat dalam menentukan seperti halnya rasio tenaga kependidikan, syarat untuk menentukan tunjangan profesi guru (TPG), Biaya Operasional Sekolah (BOS) dan masih banyak lagi kebijakan-kebijakan pusat yang nantinya akan melakukan pengambilan datanya dari aplikasi Dapodik, maka dari itu satuan pendidik harus melakukan Input Data maupun Update data sesuai dengan bukti fisik yang ada kedalam Aplikasi Dapodik untuk mendapatkan data yang akurat cepat, lengkap, valid dan up to date, maka Operator Sekolah berperan penting dalam melakukan pendataan dan sekaligus pengguna dari aplikasi Dapodik tersebut.

Kondisi demikian mengarahkan pemerintah untuk mendorong pembangunan melalui kebijakan pada sektor Pendidikan. Pemanfaatan Dapodik menjadi salah satu cara dalam melakukan pengawasan terhadap permasalahan yang dihadapi sekolah yang selanjutnya menjadi acuan pemerintah untuk melakukan langkah-langkah perubahan untuk peningkatan kualitas Pendidikan di Indonesia.

Bentuk kebijakan yang dimaksud dalam keterkaitannya penggunaan Aplikasi Dapodik adalah kebijakan-kebijakan yang menyangkut perhatian pemerintah terhadap kebutuhan tenaga pendidik dengan rasio siswa yang ada, pengalokasian anggaran dalam meningkatkan infrastruktur Pendidikan yang tepat sasaran dan pembenahan masalah-masalah lainnya terkait Pendidikan. Permasalahan yang tentunya dapat dilihat melalui pelaporan data sekolah yang di input dalam aplikasi Dapodik tersebut.

Adapun yang menjadi faktor penghambat dalam pemanfaatan sistem Dapodik secara umum telah dijelaskan pada pembahasan sebelumnya. Berdasarkan hasil penelitian bahwa faktor penghambat tersebut tidak terlepas banyak operator sekolah yang kurang memahami dalam penggunaan sistem informasi Dapodik, tidak ada akses untuk Operator Dinas dalam mengelola sistem informasi Dapodik sehingga kalau ada operator sekolah yang melaporkan permasalahan sistemnya susah untuk memperbaikinya langsung, operator sekolah merasa rumit dalam pengaturan data Pendidikan, kurangnya kompetensi yang dimiliki operator sekolah dalam menggunakan sistem pengelolaan Dapodik dan operator Dapodik sekolah masih manual dikerjakan oleh Kepala Sekolah.

Untuk meningkatkan mutu Pendidikan tentunya harus mempunyai faktor pendukung agar dapat diimplementasikan dan ini adalah sebuah keharusan untuk memperjelas pencapaian tujuan pendidikan yang ingin dicapai. Apalagi kebutuhan akan kebijakan pendidikan adalah fungsi pendukung pengambilan keputusan. Salah satu kebijakan Pendidikan yang terdapat pada program pemerintah pusat adalah pemanfaatan Sistem aplikasi Dapodik yang secara hirarkinya program tersebut merupakan desentralisasi Pendidikan dari Pusat ke Pemerintah Daerah bidang Pendidikan. Sehingga secara nasional Dapodik merupakan program pemerintah untuk membantu sekolah dalam melihat kondisi SDM, anggaran, dan sebagainya. Kondisi dimaksud adalah bentuk pengawasan pemerintah pusat agar memperhatikan kekurangan-kekurangan penyelenggaraan Pendidikan pada seluruh jenjang sekolah. 
Adapun faktor pendukung yang dimaksud dalam pemanfaatan Dapodik berdasarkan hasil pembahasan ini adalah Ketersediaan fasilitas computer dalam penginputan data Pendidikan sekolah, Ketersediaan SDM dalam mengoperasikan dan penginputan Data Pokok Pendidikan Sekolah, Ketersediaan anggaran yang cukup dalam operasionalnya, dan Ketersediaan jaringan internet untuk proses upload Dapodik. Ketersediaan faktor pendukung diatas dimaksudkan agar dalam proses pemanfaatan sistem Dapodik dapat terlaksana dengan baik agar kedepan mutu Pendidikan lebih fleksibel tanpa sistem yang manual.

\section{DAFTAR ISI}

Bungin, Burhan.2007. "Penelitian Kualitatif: Komunikasi, Ekonomi, Kebijakan Publik dan IImu Sosial lainnya". Jakarta:Putra Grafika

Fattah, Nanang, 2014. "Landasan Manajemen Pendidikan" PT Remaja RosdaKarya, Bandung

Hasbullah dkk, 2014. "Jaminan Kesehatan Nasional". Jakarta; PT. Raja Grafindo Persada.

Hasbullah. 2015. Dasar-dasar Ilmu Pendidikan. Jakarta: PT Raja Grafindo.

Irianto Yoyon Bahtiar, 2012. Kebijakan Pembaruan Pendidikan, Raja Grafindo Persada, Jakarta,

Komariah dan Djam'an Satori, 2010, Metodologi Penelitian. Kualitatif. Bandung : Alfabeta

Kuntjara, Esther. 2006. Penelitian Kebudayaan Sebuah Panduan Gratis. Yogyakarta: Penerbit Graha Ilmu

Nazir, Muhammad. 1998. Metode Penelitian. Jakarta: Rineka Cipta

Nazir, Moh. 2005. Metode Penelitian. Jakarta: Ghalia Indonesia.

Sedarmayanti. (2017). Manajemen Sumber Daya Manusia, Reformasi Birokrasi dan. Manajemen Pegawai Negeri Sipil (cetakan kesembilan). Bandung : PT Refika. Aditama.

Sedarmayanti. 2001. Sumber Daya Manusia dan Produktivitas Kerja. Bandung: Mandar Maju

Siagian, Sondang P, (2008). Manajemen Sumber Daya Manusia. PT. Bumi Aksara, Jakarta.

Soyomukti, Nurani. (2010). Pengantar Sosiologi. Yogyakarta: Ar-Ruzz Media.

Sukmadinata, 2006. Metode Penelitian Tindakan. Bandung : Remaja Rodsakarya

Sukmadinata (2009). Metode penelitian Pendidikan. Bandung: Remaja. Rosdakarya.

Sugiyono. (1997). Metodologi Penelitian Administrasi. Yogjakarta: CV Alfabeta.

Sugiyono. 2010. Metode Penelitian Administratif. Bandung: Alfabeta.

Sugiyono. 2011. Metode Penelitian Administratif. Bandung: Alfabeta.

Sugiyono. 2013. Metode Penelitian Pendidikan Pendekatan Kuantitatif,. Kualitatif, dan R\&D. Bandung: Alfabeta.

Sutrisno, Edy. 2013. Manajemen Sumber Daya Manusia, Cetakan Kelima. Yogyakarta: Prenada Media.

Syaiful Sagala. 2008. Konsep Dan Makna Pembelajaran. Bandung: Alfabeta 